\title{
Corporate Social Reporting Practices of Top Indian Software Firms.
}

\author{
Vijaya Murthy \\ The University of Sydney, Australia \\ and \\ Indra Abeysekera \\ The University of Sydney, Australia
}

\begin{abstract}
This study examines the corporate social reporting practices and the motivations behind such practices of the top 16 software firms in India. The 2003-2004 annual reports were analysed using content analysis to examine social reporting relating to human resource and social relations, combined with 14 case study interviews that examined managerial motives behind corporate social reporting (CSR) relating to the sample firms. When findings were analysed using legitimation strategies, the results indicate that firms use dual strategies in reporting their human resource and social relations to legitimise their activities to stakeholders.
\end{abstract}

Keywords: community; corporate social reporting; human resource; India; legitimacy.

ACKNOWLEDGEMENTS: The authors wish to express their appreciation to Professor James Guthrie for his helpful comments. The responsibility for the contents of this paper nonetheless remains entirely that of the authors.

\section{INTRODUCTION}

Firms are social creations whose survival is counted on the willingness of the society to support them (Reich, 1998). In order to have continuous support from society, firms need to undertake social activities and report such activities for the society to judge their performance. It is believed that industry sectors (such as Tobacco) that produce goods harmful to society engage in corporate social reporting (CSR) to legitimise their business activities and improve their image (Moerman \& Van Der Laan, 2005). The manufacturing of chemicals, textiles and petroleum industry sectors that emits waste into the environment engages in CSR to negate their direct and indirect negative impact on society. On the contrary, we argue that firms in knowledge-based industries (eg. banking, finance, accounting, and software firms) create fewer social hazards as these industries provide services useful to the society with socially friendly management processes. This leads us to assume that unlike industries that produce goods harmful to the society or uses processes that eventually harm the society, knowledge-based industries may not be under pressure for CSR. The objective of this study is to examine the CSR practices disclosed in the annual reports of the top Indian software firms and the motivations behind engaging in CSR by interviewing the top executives of these firms.

To accomplish the objective, the following steps were carried out. First, the frequency of disclosure of CSR was analysed using content analysis in the top 16-software firms in India disclosed in annual reports. Second, the managerial practices were analysed by conducting semistructured interviews with heads of human resources (HR) of 14 of the sample firms. Third, the intended outcomes of CSR were analysed using legitimation strategies outlined by Lindblom (1993).

Software firms were chosen for the study as they typifies a knowledge-based industry, engages in producing socially less harmful services, and has a growing importance to the Indian 
economy. With the inclusion of this introduction, the paper has been organised into seven sections. The second section provides an insight into CSR and software industry in the Indian context. Section 3 outlines the vacuum in the literature examining legitimation strategies of CSR in a knowledge-based industry such as software firms. Section 4 outlines the theoretical framework. Section 5 describes the content analysis and case study interview methodologies applied in this study. Section 6 offers the findings and interprets them in the context of legitimation strategies. In the concluding section, final remarks about legitimation strategies are made in the context of software firms acknowledging the limitations.

\section{CSR AND SOFTWARE INDUSTRY IN THE INDIAN CONTEXT}

The economy of India is undergoing a substantial transformation since the country's independence in 1947. The aftermath of the British rule left Indian economy weak and vulnerable due problems such as low GDP growth, high population, low literacy, under nourished population and poverty. India inherited an economy that had grown at an annual pace of 0.7 percent in the previous 50 years, which was less than the rate of population increase. Population growth was another major impediment to its socio-economic development. Population increased by 21.5 percent between the years 1951-1961 (Indian Child. com, 2005). For approximately 200 years, India has had a large number of illiterate (14\% literacy rate in 1947) and poorly nourished people who were trailing below poverty line (Freidman, 2000). About 47\% of India's rural population was below poverty line in $1951^{1}$ (Wikipedia).

The Indian economy started improving after independence but the pace of growth was not satisfactory. India's population reached 1 billion in the beginning of 2000, almost three times its 1951 population of 361 million. With regard to improvement in the literacy rate, the year 1991 recorded a total literacy rate of $58.7 \%$. This was due to a low rural literacy rate of $44.5 \%$ in spite of $73 \%$ literacy rate in urban India. Income inequality was high in India with thirty five percent of the population living below poverty line in 1994. Seventy-five percent of the people (350-400 million) who fell below poverty line (with less than \$2 per capita income a day) resided in rural areas (Freidman, 2000).

In spite of these persistent problems, the GDP in India grew from 5.7\% in 1980s to an average of about $6.1 \%$ in the 1990s making India one of the ten fastest growing countries in the world. The country aimed to achieve 8 per cent growth in its recent plan period between 2002-2007 (Planning Commission of India, 2002) and the GDP growth recorded for the year 2004 was 8.2\% (Neoncarrot, 2005) and for the year 2006-2007 it was 9.4\% (Wikipedia, 2007). This could be attributed to the liberalisation of the economy in 1991 and the consequent growth of the software industry in the country. Economic reforms of 1991 changed the Indian business context from one of state-centered, control orientation, to a free, open market orientation - especially for hi-tech companies. It allowed Indian companies to start competing effectively on a global scale (Murthy, 2002).

The IT sector is one of the fastest growing segments of Indian industry, growing from Rs.13,200 crores (approx AUD 4.125 billion) in 1992-93 to Rs.80,884 crores (approx AUD 25.276 billion) in 2001-02 of which 60\% (Rs.48,134 crores- approx AUD 15 billion) is accounted for by the software and service providers (Planning Commission of India, 2002). Software exports of Rs.36,500 crores (approx AUD 11.4 billion) accounts for 86\% of the total IT exports of India. India's software and service industry has grown rapidly over last few years and has attracted

\footnotetext{
${ }^{1}$ The poverty threshold, or poverty line, is the minimum level of income deemed necessary to achieve an adequate standard of living (http://en.wikipedia.org/wiki/Poverty_line, retrieved on $7^{\text {th }}$ June, 2007)
} 
attention from many quarters including attracting talent from other industries, capital markets, and policy makers (Ambastha \& Momaya, 2004).

As discussed above, the software industry has been a forerunner in developing the economy of India both by generating revenue and providing employment (Shikarpur, 2004, p. 15). The industry's contribution to the national economic output has nearly tripled - from 1.2 percent in the fiscal year (FY) 1997-98 to 3.5 percent in the FY 2003-04 (Nasscom, 2003). Moreover, around 284,000 professionals were employed by the software and services exporter industry in 1999-2000 that increased to one million in 2004-05. The Indian software and services exporter industry is expected to contribute 7 percent of the country's GDP by 2009, providing direct employment to more than 2.2 million people and indirect employment to nearly twice that number. The Indian IT software and services market is expected to grow to US\$ 50 billion by 2009 (Nasscom, 2003).

Notwithstanding its contributions to the GDP growth of the country and the employment opportunities created by the software industry, the software industry is also obliged to meet its responsibilities towards curbing the other social problems prevalent in India. The problems have become more complex due to the size of the country, its huge population, wide regional and gender disparities, and economic factors such as poverty and illiteracy. There is a call for action from people, organisations, communities, government agencies, and international organisations to help the country with its social problems. Therefore to fulfil their 'responsibilities' towards the society in which they function the software firms are required to deal with the social problems and contribute more than just economic services (Sharma \& Talwar, 2005). There has also been widespread concern that the idea of triple bottom line reporting or sustainability reporting has not been high on the agenda for Indian companies (Kaushalam, 2004). Kaushalam (2004) justifies this by pointing out that only one Indian corporate entity made it to the top 100 companies in S\& P's 'The Global Reporters 2004 Survey of Corporate Sustainability Reporting'.

Though CSR is no longer a new phrase in Indian organisations and some software firms have already incorporated corporate social responsibility concepts in their core values, it seems that there is no real consensus about what it really means (Nasscom, 2006). Based on a survey conducted by Nasscom on software firms' understanding of corporate social responsibility and its importance to their firms, Nasscom claimed that the key barriers to corporate social responsibility and therefore CSR is dearth of knowledge on the concept, insufficient resources and the lack of commitment. Moreover, though many international standards were available to support, measure and assist companies implementing CSR, most of the Indian firms did not follow the guidelines. Therefore, given the background of the Indian economy, the rapid growth of software industry in India and its influence on the growth of the economy, the recent adoption of corporate social responsibility concept in the core values of the software firms and the need for corporate social responsibility in India, it would be beneficial to examine the CSR practices of the top software firms of India.

\section{REVIEW OF LITERATURE}

\section{Corporate social reporting definitions:}

Gray, Owen, \& Maunders, (1987) define CSR as "the process of communicating the social and environmental effects of organizations' economic actions to particular interest groups within society and to society at large”. Similarly, Perks (1993) defined corporate social reporting as the disclosure of those costs and benefits that may or may not be quantifiable in money terms arising from economic activities and substantially borne by the community at large or other stakeholders. The US National Association of Accountants' set up a committee on accounting for Corporate Social Performance in 1972. The Committee, which set an early foundation on CSR 
issued its first report, in which CSR was defined as "[t]he identification, measurement, monitoring and reporting of the social and economic effects of an organisation on society" (NAA, 1974). This study adopted the CSR guidelines issued by The National Association of Accountants (NAA) as a framework to analyse the CSR practices of top Indian software firms for a number of reasons. First, this study examines its data from the perspective of economic consequences. Second, recent studies on CSR conducted in the third world countries have used it as guidelines for their research (Batra, 1996; Imam, 2000; Raman, 2006). Third, as outlined in the previous section, the Indian companies do not adopt the international standards (such as Global Reporting Initiative's Sustainability Reporting Guidelines) to report on their social activities, which do not allow the study to use these contemporary guidelines. Hence, the earliest guidelines issued by NAA are employed as they provide a general classification of CSR elements (Hamid, 2004).

Three major areas of CSR identified by the NAA committee are human resources, community development, and environmental activities. Although all three major areas of corporate social performance are important, in analysing corporate social activities, this study has focused on community and human resources areas only. In India, the high levels of poverty and the growing disparity between haves and haves-not has encouraged the development of communities' activities. Moreover, the high level of unemployment has stimulated firms to offer employment (Nasscom 2003). Hence these two areas of CSR seem to be important from the Indian perspective. Moreover, it is mandatory for all the firms to disclose information about their environmental activities in their Director's report section of the annual report as per Sec. 217 (1e) of the Indian Companies Act, 1954. Only two companies from the sample have provided voluntary reporting on environmental activities. Therefore, though environmental reporting is important, this study excluded environmental reporting for its analysis on CSR for lack of voluntary environmental reporting by the software firms.

Human resource reporting includes social activities directed towards the well being of employees like improvement of employment practices, training programmes, working conditions, employee benefits and safety at work. Community development reporting consists of social activities that are beneficial to the general public like housing construction, financing of health services, activities for employees, food programmes and community planning and improvement.

\section{Corporate Social Reporting practices around the globe}

\section{Western Countries:}

There has been multitude of studies on CSR of western countries. Two decades ago, a gradual increase in CSR has been observed in Australia over the years (Guthrie \& Mathews 1985; Trotman 1979) although a gradual decline has been noticed in the USA among firms (Ernst and Ernst 1978). However, more recent research in the mainland European countries indicate that firms have extensively reported on their corporate social activities (Roberts, 1991). Hackston \& Milne (1996) found that a large majority of CSR made by New Zealand companies tend to be declarative and good news on primarily human resources followed by environment and community themes. Compared to the US and UK companies, New Zealand companies have lower social disclosures. In a study of CSR of six Irish financial institutions Douglas Doris, \& Johnson (2004) found that these institutions were well behind their European counterparts with regard to the quality and quantity of social disclosure in annual reports. They attributed the reason for poor CSR practices to the voluntary nature of social disclosure in Ireland. Thus, though there has been a mixed opinion on CSR in western countries, it could be noticed there is a gradual increase in corporate social reporting. 


\section{Asian Countries:}

CSR experience in Asian countries has also been mixed. Firms in Singapore and Bangladesh have limited CSR, but CSR of firms in Thailand matches that of the developed nations. Tsang (1998) examined the annual reports of listed firms (from 1986 to 1995) across several industry sectors in Singapore, and revealed that one half of them did not have any CSR disclosures throughout the ten-year period. Examining 1996-1997 annual reports of listed firms from Bangladesh, Imam (2000) has reported that many firms hardly engage in CSR. Kuasirikun and Sherer (2004) analysed annual reports of 1993 and 1999 of large Thai listed firms across different industry sectors and confirmed that their CSR disclosures were comparable to CSR disclosure of listed firms in Western nations.

India:

In the context of India, CSR studies were few and limited. Singh and Ahuja (1983) conducted the first study in India on CSR of 40 Indian public sector companies for the years 1975/1976 and found that 40 percent of the companies disclosed more than 30 percent of total disclosure items included in their survey. Hegde, Bloom, \& Fuglister (1997) conducted a case study of the Steel Authority of India (SAIL), a public sector company. They found that SAIL published a Social Income Statement and a Social Balance Sheet to measure the social benefits to employees, public and the community and the cost involved. These reports showed the efforts made by SAIL in fulfilling its social objectives and responsibilities. The latest study of CSR practices in India was conducted by Raman (2006). Raman used content analysis technique to examine the chairman's message section in the annual reports of the top 50 companies in India to identify the extent and nature of social reporting. This study concluded that the Indian companies placed emphasis on product improvements and development of human resources. Community development issues were given relatively less space in the chairman's messages.

Alongside the studies mentioned above, research on corporate social activities has been conducted in various other countries such as Portugal, UK, Malaysia, Cyprus and Canada (Abreu, David, \& Crowther, 2005; Jones, Comfort, \& Hiller, 2005; Md Zabid \& Ibrahim, 2002; Papasolomou-Doukakis, Krambia-Kaardis, \& Katsioloudes, 2005; Vallee, 2005) and different industry sectors such as finance industry, banking sector, hospitality industry, petroleum industry in those countries (Douglas et al., 2004; Goldreyer \& Diltz, 1999; Longo, Matteo, \& Bonoli, 2005; Piacentini, MacFadyen, \& Eadie, 2000). This study will contribute to the literature and enhance the understanding of CSR practices in the context of software industry that is rapidly growing, while experiencing a global skills shortage.

\section{Motives for CSR:}

The literature seems to be inconsistent with the clarification on the motives of providing CSR. According to Idowu \& Towler (2004) some motives for CSR include increased customer loyalty, more supportive communities, the recruitment and retention of more talented employees, improved quality and productivity and the avoidance of potential reputation risks which may arise from environmental incidents. It also appears that greater transparency is a key motivation for CSR in firms (Guthrie \& Mathews 1985b; Roberts 1991; Trotman 1979). According to O’Dwyer (2002) CSR in Ireland seemed to be motivated by legitimacy purposes but was seldom attained. The Irish companies avoided CSR due to societal scepticism. O’Dwyer further pointed out that the Irish managers were concerned with accountability to wider society and the motives were outside of selfinterest. On the other hand, Henderson (2006) espoused that some firms may adopt CSR but their attitudes towards the society may remain unchanged and they are directed by self-interest, 
commercial dictates and political advantage. Thus the prior studies not only failed to clarify the motives behind CSR, but also have failed to investigate the motives along with the companies' reporting practices to get a comprehensive picture of CSR.

\section{THEORETICAL FRAMEWORK}

Legitimacy theory is the most widely used theory to explain social reporting practices of a firm (Adams, Hill, \& Roberts, 1998; Deegan \& Gordon, 1996; Guthrie \& Parker, 1989; Milne \& Patten, 2002; Moerman \& Van Der Laan, 2005; O'Donovan, 2002; O'Dwyer, 2002; Patten, 1992; Wilmhurst \& Frost, 2000). Legitimacy theory emphasise that corporate management will react to community expectations (Deegan, Rankin, \& Tobin, 2002; Patten, 1992) and human resource management (Campbell, 2000; Deegan et al., 2002). As explained earlier, the software firms do not produce harmful products nor do they use processes that are harmful to the society. Therefore, the Indian community might expect the software firms to report information on their positive social activities such as dealing with the domestic social problems that are prevalent in India. Accordingly, the management of the software firms may legitimise their existence by reporting on the positive actions taken by them to curb poverty, illiteracy and unemployment.

Legitimacy theory posits, given a growth in community awareness and concern, firms will take measures to ensure that their activities are acceptable to stakeholders (Wilmhurst \& Frost, 2000). O'Donovan (2002) states that managers' legitimising strategies will differ depending on whether they are trying to gain, maintain or repair the legitimacy of their firms. Organisational legitimacy is a concept that can be used to gain insight into the motivation a firm has for providing CSR on a voluntary basis (Lindblom, 1993). Lindblom (1993) espoused that firms adopt legitimacy as a strategic process and classified this legitimation into four types of strategies, which later authors have duly acknowledged (e.g., Neu, Warsame, \& Pedwell, 1998):

\footnotetext{
First strategy: Legitimation involves bringing the firm's output, methods and goals into conformity with popular views and makes internal adjustment to close legitimacy gap. These firms seek to educate their stakeholders about the organisation's intentions to improve the performance;

Second strategy: The firms may decide that no adjustment in its output, methods, and goals is required and attempts to demonstrate the appropriateness of its existing output, methods and goals. These firms seek to change the stakeholders' perceptions on the organisational event (but without changing the organisation's actual performance);

Third strategy: Legitimation proceeds by identifying firm's output, methods and goals with the popular perception of what is appropriate without any attempt at actual conformity. These firms manipulate the perceptions of the relevant publics rather than educating and informing them; and,

Fourth strategy: Legitimation efforts result in a strategy wherein the firm attempts to bring popular views into conformity with its output, methods and goals. These firms seek to change external expectations about their performance, without making internal adjustment to close legitimacy gap.
}

Legitimacy is one of the factors that motivate the management to adopt and report social practices (Guthrie \& Parker, 1989). The increasing public awareness all over the world including India is influential as a driver of corporate performance and this has positively contributed towards the country's corporate social activities (Patten, 1992; Sharma \& Talwar, 2005; Zairi \& Peters, 2002). In the context of the Indian software firms, Lindblom's strategies are useful for analysing the motives for CSR.

\section{METHODOLOGY}

The external CSR practices of the software exporters were examined by analysing the contents of the annual reports for the year 2003-2004. The dataset included the top 16 software firms by total revenue listed on the Mumbai Stock Exchange. The management motivation for external reporting of these firms was captured by semi-structured interviews with Human Resources (HR) heads of 14 out of the 16 firms in the sample. These firms have been identified in this study 
by alphabetical letters to disguise identity as required in the ethics agreement between the researchers and the firms.

\section{Reporting practices disclosed in annual reports}

The annual reports in the sample were analysed to quantify voluntarily disclosed CSR information using content analysis (Krippendorff, 1985). Content analysis is an established research technique in CSR (Abbott \& Monsen, 1979; Ernst and Ernst, 1978; Guthrie \& Mathews, 1985; Guthrie \& Parker, 1990; Zeghal \& Ahmed, 1990). Annual reports are the most widely used documents in the analysis of corporate social activities in spite of a broad range of corporate documents (such as brochures, press releases and the like) released to the public to provide information about an organisation's social practices. Research has commended annual reports for their credibility (Tilt, 1994), regularity (Niemark, 1992), accessibility and reporting useful information to stakeholders (Deegan \& Rankin, 1997). Annual reports are considered as a vital document constructing CSR of firms (Gray et al.,1995). Furthermore, our initial investigations revealed that software firms in the sample did not release any discrete social reports, and as such their CSR is confined to their annual reports.

There is considerable debate in the literature on the choice of the most appropriate 'unit of analysis' that should be used in content analysis (Gray, Kouhy \& Lavers, 1995). Unit of analysis could take the form of words, phrases, characters, lines, sentences, pages or proportion of pages devoted to different categories of social disclosure (Unerman, 2000). Coding of words or areas of pages as a basis to derive measures of social disclosure has found to decrease the reliability of the analysis (Milne \& Adler, 1999). Number of pages as a measure of disclosure is often said to be problematic due to differences arising from font size, margins, graphics etc., while the number of words causes difficulties due to concise or verbose styles of writing (Hackston \& Milne, 1996). Based on Milne and Adler (1999), this study used number of sentences for coding and measurement of CSR since sentences provide complete, meaningful and reliable data for further analysis. These sentences were first counted to ascertain the volume of reporting of each attribute. Then the information content from each sentence was further analysed in an effort to measure the quality of reporting of the attributes.

As previously noted, the two categories, namely human resources and community development were selected for this study. Based on the recommendations of the NAA committee and other prior studies (Batra, 1996; Imam, 2000) each category is identified by a number of attributes. Human resource category included training, employee numbers, career development, equity issues, compensation plans, employee benefits, and safety. Community development category included community planning, children education and upliftment of poor, health services, and food programs.

\section{Management motives for external reporting through case study interviews}

Exclusive focus on annual reports may lead to an incomplete picture of CSR practices (Unerman, 2000). Hence, to gain a deeper understanding of managerial motivation for social disclosures in annual reports of the firms, 14 semi-structured interviews were conducted with the Human Resources (HR) heads of these firms. The HR heads at the senior level are aware of both short-term and long-term perspectives of their firm and their CSR agenda (Nasscom, 2006). Interrogations were in the form of semi-structured questions based on the coding framework attributes used to analyse the contents of annual reports. Each interview ranged between forty-five minutes to one hour in duration. The semi-structured interviews served as a direct comparison to CSR content analysed in annual reports, and helped in identifying legitimation strategies of CSR 
(Miller \& Crabtree, 1999) since the respondents were allowed time and scope to express their views to the questions raised by the researchers (Singleton \& Straits, 2005).

The study took care to minimise threats to reliability and validity of content analysis as suggested by Krippendorff (1985) and interviews as suggested by McKinnon (1988). One of the researchers re-examined the contents of the annual reports after a time interval of six months to confirm consistency in identification of the CSR attributes in the annual reports. Reproducibility test was also conducted for this study by checking the coding performed by each of the researchers individually. Steps were also taken to ensure face validity and process-oriented validity by using the previous studies for the selection of content attributes.

With case study interviews, the study used the steps suggested by McKinnon (1988) to increase the validity of the interview results. Sending the information about the study to the respondents, getting approval of the chief executive officers of the software firms, making contacts over the phone prior to the interview and conducting the interviews in a highly professional manner helped in reducing observer caused bias. By separating collection of data and the analysis of data by a period of time and checking the interview notes of both researchers for consistency interviewer bias was minimised. Thus the combination of content analysis and case study interviews using the same framework enabled this study to gain insight into the existing reporting practices and the motives behind such reporting.

\section{FINDINGS AND INTERPRETATION}

The findings presented here and their interpretations are based on the aggregated information of the sample firms rather than individual firms. The reporting practices of the sample firms by sentence count is summarised below in Table 1 which shows that reporting of human resources category was slightly higher than that of community development.

\section{Table 1}

Sentence count as a percentage of total social activity reported

\begin{tabular}{|l|c|c|}
\hline Social activity category & Sentence count & Percentage \\
\hline Human resources & 301 & 51 \\
\hline Community development & 285 & 49 \\
\hline
\end{tabular}

\section{Human Resources}

The firms sought to educate stakeholders about their intentions to improve performance by reporting more on the human resource category. Interviewees reported that (not noticeable from annual reports) stakeholders knew less about the processes adopted to improve the employees' performance conforming to the first type of legitimation strategy outlined by Lindblom (1993).

As shown in Table 2, training was the most frequently reported (27\%) followed by employee number (22\%). Employee benefits (8\%) and employee safety issues (5\%) were the least reported in annual reports in the human resource category. 


\section{Table 2}

CSR of Human resource category in annual reports in the sample

\begin{tabular}{|c|c|c|}
\hline Attribute & Sentence count & Percentage \\
\hline Training & 83 & 27 \\
\hline Employee numbers & 66 & 22 \\
\hline Career development & 55 & 18 \\
\hline Equity issues & 29 & 10 \\
\hline Compensation plan & 29 & 10 \\
\hline Employee benefits & 23 & 8 \\
\hline Safety & 16 & 5 \\
\hline
\end{tabular}

The most frequently reported category of human resource indicated that firms in the sample have engaged in a multitude of activities to foster their development. One of the key activities was training their employees. A key driver of training was to benefit mutually the firm and employees as the core aim of the business is economic efficiency of the firm. The respondents unanimously acknowledged that training was necessary to develop the skills of their professionals to increase the competence of their organisation. A respondent exclaimed:

"Our learning agenda is driven by a holistic framework.... we give importance on role-based training, business leadership programme and so on...I can't insist on the importance of training. It is our backbone and we need it to keep us in this high performance field...."

This was also brought out by the contents of the annual report:

It places great emphasis on training and development of employees at all levels and seeks to achieve more close alignment between their aspirations and the strategic objectives of the organisation through intensive communication of the corporate strategic objectives to all its employees across the globe. (Firm C, Annual Report, 2004)

The importance of training employees has intensified due to increasing competition, and ensuring the maintenance of high standards for their services. Several respondents claimed that they expected reporting on training to influence the economic success of the firm. As a respondent noted, the software firms recognised that to achieve sustainable excellence in all aspects of performance, they should concentrate on maximising the contribution of employees through training and development. Training, according to another respondent, helped in maintaining and improving the quality of their workforce. The following example from the annual report of Firm I highlight the importance placed by the firm on its training initiatives.

"Channel W also provides value to employees by facilitating E-training. It enables employees to catch up with their learning and development needs at their own pace. Keeping the talent contemporary is a large ongoing process in Firm I".

Therefore the motivation behind reporting on training seems to be influenced by the idea that the firms are continuously seeking to educate their stakeholders about their intentions to improve their performance, consistent with the legitimising strategies outlined by Lindblom (1993).

The HR heads interviewed noted that the software industry in India is experiencing an exponential growth. This rapid expansion demands increasing numbers of employees with skills relevant to the software industry to sustain its growth. As the respondents noted, the increase in employee numbers reported, signals to the stakeholders about growth of firms and corresponding increase in demand for skilled manpower. Based on the respondents' feedback, it could be understood that the purpose behind reporting employee numbers was to inform the stakeholders about the economic expansion of the firms and the growing demand of skill-specific employment in their firms. This is also confirmed in the annual report of Firm E: 
The acquisition added over 170 employees to Firm E's resource pool, many of whom are specialists in banking technology and operations, thereby further contributing to Firm E's strengths in the Banking, Financial services and insurance space.

The annual reports did not elaborate the processes adopted in developing the careers of staff but interview respondents noted that they supported career development of staff to attract, motivate and retain the best possible talent. The following respondent's comment typifies the general approach of firms in relation to career development.

"We (The software firms) literally fight among each other to attract and retain the top quality talent....this is possible only if we show our employees their career path, give them both monetary and non-monetary .... This atmosphere gives them a feeling of energy and vitality and freshness. Moreover, the employee looks for a firm that values his career aspirations and helps him achieve his goals."

The growing demand of relevant skills has created an employee-driven rather than employer-driven market creating additional cost to the firm in hiring, training, and retaining employees. The motive behind meeting career aspirations of staff was to increase retention of staff. The motivation behind reporting of career development seems to be to inform stakeholders about the firms' efforts to hire and retain skilled employees.

Although annual reports have not extensively reported about equity related issues, interview findings suggested that firms did not discriminate employees based on religion, nationality, caste or creed, and encouraged women employees to join their work force. According to the respondents, an employer's commitment to workplace diversity was not a politically or morally correct obligation, but a business imperative that reduced conflict and fostered creativity. A respondent from one of the top five software firms exclaimed:

"Diversity kills politics in the company. We encourage diversity since it derisks the organisation and promotes creativity that is the backbone of our business."

As respondents outlined the motivation here was also to achieve better economic performance together with creating equal employment opportunity. Few annual reports also reiterated this point:

With the technology world emerging as a level playing field building cross-cultural teams has become am imperative. (Firm A, Annual Report, 2004)

The cultural benefits of working with a multi-cultural team from an organisation standpoint have matched the synergy benefits of our acquisitions from a customer standpoint. (Firm F, Annual Report, 2004)

It was found that though the firms gave importance to equal employment opportunity, they did not report much on this issue since according to the respondents, the firms' management felt that it was beneficial to report on issues such as training and employee numbers. It could be inferred that even with the limited reporting of equal employment opportunity, the firms seem to adopt the first strategy of educating the stakeholders about their performance improvement (Lindblom, 1993).

Though the firms adhered to strict safety standards, they were the least reported in the annual reports. One of the respondents claimed that they did not report about the safety standards of their services since they felt that there is little interest among stakeholders, or stakeholders have taken that fact as granted, and reporting in annual reports do not add to the interest of stakeholders.

\section{Community development}

The interviews suggested that firms have a genuine interest to contribute to community development. Some respondents claimed that they do so without ulterior motives but few others indicated that they involved in community activities for their indirect growth. This contradictory information is captured in the following annual report quotes: 
"Your Company believes that we have a responsibility to serve the underprivileged and the satisfaction derived from serving the needy is unparalleled.” (Firm D, Annual Report, 2004)

"Firm $F$ is an element in the social fabric, and unless we expand possibilities for the larger community, we will not create significant growth opportunities for Firm F."

The motivation for the majority of software firms to report on community development was an effort to change the stakeholders' perceptions on the organisation without changing its actual economic performance (Lindblom, 1993).

As shown in Table 3, the community development category represents community development and planning activities (43\%), children's education, and upliftment program of the poorer sectors of the community (41\%) in the descending frequency of reporting.

\section{Table 3}

CSR of community development category in annual reports in the sample

\begin{tabular}{|c|c|c|}
\hline Attribute & Frequency count & Percentage \\
\hline $\begin{array}{c}\text { Community planning } \\
\text { Child education \& upliftment of } \\
\text { poor }\end{array}$ & 122 & 43 \\
\hline Health services & 117 & 41 \\
\hline Food program & 42 & 15 \\
\hline
\end{tabular}

Respondents stated that community development has always been an important focus of the software firms in India. They added that the most important social issue in India is the need for proper planning and development of the community. The children in families below the poverty line do not have access to basic education. Moreover, a literate population is necessary for improving the economy. The annual report of Firm $\mathrm{C}$ highlights the importance given to education.

We initiated "Firm C Applying Thought in Schools" to help bring about a fundamental transformation in the Indian school education system - to prepare our children with life-skills, and to help them realise their potential.

Another example from the annual report of Firm K:

Our "Firm K for children" community initiative is focused on improving children's education and health

It is in this context that the software firms take an interest on children's education and the upliftment of the poor as typified by the following respondent's comment.

"Our company has adopted a village nearby and our employees and their family participate in village activities like health programs.... we have adopted the village school given them computers, do all that we can to bring up the children because we feel that educating children is absolutely necessary."

The interviews revealed that firms undertake health service initiatives such as building hospitals, treating cancer patients, blood donation camps and food programs (such as midday meals for school children or providing food for people affected by flood and famine). According to some of the respondents, the firms understand that they are social entities obtaining their resources from the society. Hence, they feel that firms have the responsibility of giving back to the community. An example from an annual report:

...thus completing the cycle; what came from the people has gone back to the people many times over.(Firm A, Annual Report, 2004)

Furthermore, they recognise that as quality practitioners they (the firms) have to give as much importance to community activities as they give to their products, processes and people. This is evident from the reporting in the annual reports. 
"The company participates in the 'Firm A Business Excellence Model', which emphasizes quality, leadership, strategic planning, customer orientation and services, process orientation, human relations, shareholder value and commitment to community development."

Many firms in the sample also engaged in community development in an ad-hoc manner to meet calamities due to natural disasters that arise in the local or national community. Such engagements were initiated by employees rather than firms. The firms contributed to community development programs by topping up the monetary contribution made by its employees towards community development programs. HR heads stated that this approach of topping up the contribution by the firm brings out a 'humane' aspect of the firm to employees and the community. Some examples from the annual report:

In the wake of the Tsunami disaster, which left thousands homeless, the company and its employees contributed 1 crore for the relief and rehabilitation of the affected families.

“...medical relief for the flood-hit village of Bangrisingha, Orissa (Akanksha, Bhubaneswar Development Centre); donations to the SOS village of Rajpura (Mohali Development Center), etc.”

\section{CONCLUSION}

The study demonstrates that motivations behind human resource and community development aspects of CSR are complex, particularly in an emerging economy. In studying the two categories of social activities - human resource category and community development category, this study found support that firms employ CSR to legitimise their activities. The fact that software industry in India is expanding rapidly and experiencing a shortage of skilled labour has shaped their CSR practices in relation to their human resource category. The research demonstrates that Indian software firms support staff training and career development for economic reasons. Their CSR on human resources highlights the efforts taken by the firms to attract, and retain skilled employees in the firms. However, the motivation for reporting on community development activities emanates from a genuine interest of these firms to help the society.

This study provides insights to the CSR practices of software firms in India. However, these findings should be interpreted acknowledging the following limitations. This study has ignored longitudinal variations and the sample organisations comprised the top software firms in India, restricting generalisation to the firms examined in the study. The research assumes that the interviewees' comments truly reflect the social motivations of the firms. Also, the interviewees were responsible for the CSR agenda in the firms, however they may not be responsible for reporting the corporate social information in the annual reports.

This study, while providing valuable insights, highlights the dearth of research of CSR in emerging economies and opens up many avenues for further research. Such research could employ alternative methodological approaches such as field studies to obtain a broader understanding of the legitimation strategies employed by software exporter firms. Further, the content analysis could be extended to other media. Additionally, a study could compare CSR practices of firms in knowledge-based industry and firms in a manufacturing industry, and CSR practices of Indian software firms with those of software firms in other countries. Finally, extending this study to other aspects of CSR (such as service contribution and relations with the environment) may elucidate other legitimation strategies adopted by firms. 


\section{REFERENCES}

Abbott, W. F., \& Monsen, R. J. (1979). On the measurement of corporate social responsibility: self reported disclosures as a method of measuring corporate social involvement. Academy of Management Journal, Vol 22(3), 510-515.

Abreu, R., David, F., \& Crowther, D. (2005). Corporate social responsibility in Portugal: empirical evidence of corporate behaviour. Corporate Governance, Vol 5(5), 3-18.

Adams, C. A., Hill, W. Y., \& Roberts, C. B. (1998). Corporate social reporting practices in Western Europe: legitimating corporate behaviour? British Accounting Review, Vol 30(1), 1-21.

Ambastha, A., \& Momaya, K. (2004). Challenges for Indian Software Firms to Sustain their Global Competitiveness. Singapore Management Review J1 - Singapore Management Review, 26(2), 65-77.

Batra, G. S. (1996). Dynamics of social auditing in corporate enterprises: a study of the Indian corporate sector. Managerial Auditing Journal, Vol 11(2), 36-45.

Campbell, D. J. (2000). Legitimacy theory or managerial reality construction? Corporate social disclosure in Marks and Spencer Plc corporate reports, 1969-1997. Accounting Forum (Blackwell), Vol 24(1), 80.

Deegan, C., \& Gordon, B. (1996). A study of the environmental disclosure policies of Australian corporations. Accounting and Business Research, Vol 26(3), 187-199.

Deegan, C., \& Rankin, M. (1997). The materiality of environmental information to users of annual reports. Accounting, Auditing \& Accountability Journal, Vol 9(2), 50-67.

Deegan, C., Rankin, M., \& Tobin, J. (2002). An examination of the corporate social and environmental disclosures of BHP from 1983-1997: a test of legitimacy theory. Accounting, Auditing \& Accountability Journal, 15(3), 312343.

Douglas, A., Doris, J., \& Johnson, B. (2004). Corporate social reporting in Irish financial institutions. The TQM Magazine, Vol 16(6), 387-395.

Ernst and Ernst. (1978). Social Responsibility Disclosure: Survey of Fortune 500 Annual Reports. Cleveland, OH.

Freidman, C. (2000). A demographic Profile of India. Retrieved 26th September, 2005, from http://www.prcdc.org/summaries/india/india.html

Goldreyer, E. F., \& Diltz, D. J. (1999). The performance of socially responsible mutual funds: incorporating sociopolitical information in portfolio selection. Managerial Finance, Vol 25(1), 23-36.

Gray, R. H., Kouhy, R., \& Lavers, S. (1995). Methodological themes: constructing a research database of social and environmental reporting by UK companies. Accounting, Auditing \& Accountability Journal, Vol 8(2), 78-101.

Gray, R. H., Owen, D., \& Maunders, K. (1987). Corporate Social Reporting. Englewood Cliffs, NJ.: Prentice-Hall.

Guthrie, J., \& Mathews, M. R. (1985). Corporate social accounting in Australasia. Research in Corporate Social Performance and Policy, Vol 7, 251-277.

Guthrie, J. E., \& Parker, L. D. (1989). Corporate Social Reporting: A Rebuttal of Legitimacy Theory. Accounting \& Business Research, Vol 19(76), 343-352.

Guthrie, J. E., \& Parker, L. D. (1990). Corporate social disclosure practice: a comparitive international analysis. Advances in Public Interest Accounting, Vol 3, 159-175.

Hackston, D., \& Milne, M. J. (1996). Some determinants of social and environmental disclosures in New Zealand companies. Accounting, Auditing \& Accountability Journal, Vol 9(1), 77-108.

Hamid, F. Z. A. (2004). Corporate social disclosure by banks and finance companies: Malaysian evidence. Corporate Ownership \& Control, 1(4), 118-130.

Hegde, P., Bloom, R., \& Fuglister, J. (1997). Social financial reporting in India: A case. The International Journal of Accounting, Vol 32(2), 155-172.

Henderson, J. C. (2006). Corporate social responsibility and tourism: Hotel companies in Phuket, Thailand, after the Indian Ocean tsunami. International Journal of Hospitality Management In Press, Corrected Proof.

Idowu, S., \& Towler, B. (2004). A comparative study of the contents of corporate social responsibility reports of UK companies. Management of Environmental Quality: An International Journal, Vol 15(4), 420-437.

Imam, S. (2000). Corporate social performance reporting in Bangladesh. Managerial Auditing Journal, Vol 15(3), 133141.

Indian Child. com. (2005). Population of india, india Population: Structure and dynamics. Retrieved 22nd September, 2005, from http://www.indianchild.com/population_of_india.htm

ISO 17799-BS 7799. (2005). Retrieved 2nd August, 2005, from http://www.induction.to/bs7799/

Jones, P., Comfort, D., \& Hiller, D. (2005). Corporate social responsibility and the UK's top ten retailers. International Journal of retail \& Distribution management, Vol 33(12), 882-892.

Kaushalam, K. (2004, 26th December). Tata Steel lone Indian Co in S\&P's CSR rankings. The Financial Express.

Krippendorff, K. (1985). Content Analysis: An introduction to its Methodology (Fifth Printing ed.). Beverly Hills, London: Sage Publication.

Kuasirikun, N., \& Sherer, M. (2004). Corporate social accounting disclosure in Thailand. Accounting, Auditing \& Accountability Journal, Vol 17(4), 629-660. 
Lindblom, C. K. (1993). The implications of organizational legitimacy for corporate social performance and disclosure. Paper presented at the Critical Perspectives on Accounting Conference, New York, NY.

Longo, M., Matteo, M., \& Bonoli, A. (2005). Corporate social responsibility and corporate performance: the case of Italian SMEs. Corporate Governance, Vol 5(4), 28-42.

McKinnon, J. (1988). Reliability and validity in field research: Some strategies and tactics. Accounting, Auditing and Accountability Journal, 1(1), 34-54.

Md Zabid, A., \& Ibrahim, S. (2002). Executive and management attitude towards corporate social responsibility in Malaysia. Corporate Governance, Vol 2(4), 10-16.

Miller, W. L., \& Crabtree, B. F. (1999). Depth Interviewing. Doing qualitative research. London: Sage Publications.

Milne, M. J., \& Adler, R. W. (1999). Exploring the reliability of social and environmental disclosures content analysis. Accounting, Auditing \& Accountability Journal, Vol 12(3), 237-256.

Milne, M. J., \& Patten, D. M. (2002). Securing organizational legitimacy. An experimental decision case examining the impact of environmental disclosures. Accounting, Auditing \& Accountability Journal, Vol 31(4), 439-457.

Moerman, L., \& Van Der Laan, S. (2005). Social reporting in the tobacco industry: all smoke and mirrors? Accounting, Auditing \& Accountability Journal, Vol 18(3), 374-389.

Murthy, N. (2002, 19 ans 20 April). The impact of economic reforms on the industry in India-A case study of the software industry. Paper presented at the The Indian Economy Conference.

Nasscom. (2003). The Indian ICT Sector: Facing Manpower Challenges. Retrieved 25th May, 2005, from http://www.nasscom.org/artdisplay.asp?cat_id=734

Nasscom. (2006, 14th September, 2006). Nasscom Foundation. NASSCOM Newsline. Retrieved 14th September, 2006.

, from http://www.nasscom.in/Nasscom/templates/NormalPage.aspx?id=11088

National Association of Accountants. (1974). Accounting for corporate social performance: measurement of cost of social actions. Management Accounting, 56(September), 2-8.

Neoncarrot. (2005). Economy \& employment stats, facts and figures. Retrieved 26th May, 2005, from http://www.neoncarrot.co.uk/h_aboutindia/india_economy_stats.html

Neu, D., Warsame, H., \& Pedwell, K. (1998). Managing Public Impressions: Environmental disclosures in annual report. Accounting, Organizations and Society, 23(3), 265-282.

Niemark, M. K. (1992). The hidden dimensions of annual reports, sixty years of social conflict at General Motors. Princeton, New Jersey.: Markus Weiner Publishing.

O'Donovan, G. (2002). Environmental disclosures in the annual report. Extending the appicability and predictive power of legitimacy theory. Accounting, Auditing \& Accountability Journal, Vol 15(3), 344-371.

O'Dwyer, B. (2002). Managerial perceptions of corporate social disclosure. An Irish story. Accounting, Auditing \& Accountability Journal, Vol 15(31), 406-436.

Papasolomou-Doukakis, L., Krambia-Kaardis, M., \& Katsioloudes, M. (2005). Corporate social responsibility: the way forward? Maybe not!: A priliminary study in Cyprus. European Business Review, Vol 17(3), 263-279.

Patten, D. M. (1992). Intra-industry environmental disclosures in response to the Alaskan oil spill: a note on legitimacy theory. Accounting, Organisation and Society, Vol 17(5), 471-475.

Perks, R. W. (1993). Accounting \& Society. London: Chapman \& Hall.

Piacentini, M., MacFadyen, L., \& Eadie, D. (2000). Corporate social responsibility in food retailing. International Journal of Retail \& Distribution management, Vol 28(11), 459-469.

Planning Commission of India. (2002). 10th Five Year Plan (2002-2007). Retrieved 24th March, 2005, from http://planningcommission.nic.in/plans/planrel/fiveyr/welcome.html

Raman, R. S. (2006). Corporate social reporting in India - A view from the top. Global Business review, 7(2), 313-324.

Reich, R. B. (1998). The new meaning of corporate social responsibility. California Management Review, 40(2), 3-17.

Roberts, C. B. (1991). Environmental Disclosures: A Note on reporting practices in Mainland Europe. Accounting, Auditing \& Accountability Journal, Vol 4(3), 62-71.

Sharma, A. K., \& Talwar, B. (2005). Corporate social responsibility: modern vis-s-vis Vedic approach. Measuring Business Excellence, Vol 9(1), 35-45.

Shikarpur, D. (2004). BPO Digest (September ed.). Ulhas Latkar, Pune, India.

Singh, D. R., \& Ahuja, J. M. (1983). Corporate social reporting in India. The International Journal of Accounting, Vol 18(2), 151-169.

Singleton, R. A., \& Straits, B. C. (2005). Approaches to social research (Fourth Edition ed.). New York: Oxford University Press.

Tilt, C. A. (1994). The influence of external pressure groups on corporate social disclosure: some empirical evidence. Accounting, Auditing \& Accountability Journal, Vol 7(4), 47-72.

Trotman, K. T. (1979). Social responsibility disclosure by Australian companies. The Chartered Accountant in Australia, Vol 29, 28-54.

Tsang, E. W. K. (1998). A longitudinal study of corporate social reporting in Singapore: The case of the banking, food and beverages and hotel industries. Accounting, Auditing \& Accountability Journal, Vol 11(5), 624-635. 
Unerman, J. (2000). Methodological issues-Reflections on quantification in corporate social reporting content analysis. Accounting, Auditing \& Accountability Journal, Vol 13(5), 667-681.

Vallee, G. (2005). What is corporate social responsibility?: The case of Canada. Managerail Law, Vol 47(5), 20-46.

Wikipedia. (2007). Economy of India. Retrieved 1st December, 2007, from http://en.wikipedia.org/wiki/Economy_of_India

Wilmhurst, D. W., \& Frost, G. R. (2000). Corporate environmental reporting: a test of legitimacy theory. Accounting, Auditing \& Accountability Journal, Vol 13(1), 10-26.

Zairi, M., \& Peters, J. (2002). The impact of social reponsibility on business performance. Managerial Auditing Journal, Vol 17(4), 174-178.

Zeghal, D., \& Ahmed, S. A. (1990). Comparison of social responsibility information disclosure media used by Canadian firms. Accounting, Auditing \& Accountability Journal, Vol 3(1), 38-53. 


\begin{tabular}{|c|c|c|c|c|c|c|c|}
\hline \multirow[t]{2}{*}{$\begin{array}{l}\text { Respondent } \\
\text { Firm }\end{array}$} & \multicolumn{7}{|c|}{ Appendix 1- Human Resources Category } \\
\hline & Training & $\begin{array}{l}\text { Employee } \\
\text { numbers }\end{array}$ & $\begin{array}{l}\text { Career } \\
\text { development }\end{array}$ & Equity issues & $\begin{array}{l}\text { Compensation } \\
\text { plan }\end{array}$ & $\begin{array}{l}\text { Employee } \\
\text { benefits }\end{array}$ & Safety \\
\hline Firm A & $\begin{array}{l}\text { Train Employees on } \\
\text { specific process and } \\
\text { application }\end{array}$ & $\begin{array}{l}\text { Had a knowledge } \\
\text { workforce of } \\
2,834 \text { compared } \\
\text { to } 2,700 \text { last year. }\end{array}$ & $\begin{array}{l}\text { Encourage } \\
\text { employees to } \\
\text { upgrade their } \\
\text { skills regularly. }\end{array}$ & $\begin{array}{l}\text { Building cross- } \\
\text { cultural teams has } \\
\text { become } \\
\text { imperative. }\end{array}$ & $\begin{array}{l}\text { Fast tracking } \\
\text { career plan. ESOP } \\
\text { given based on } \\
\text { performance, level } \\
\text { and years of } \\
\text { service. }\end{array}$ & $\begin{array}{l}\text { Health and } \\
\text { welfare of } \\
\text { employees is the } \\
\text { sure foundation } \\
\text { of our } \\
\text { prosperity. }\end{array}$ & Nil \\
\hline Firm B & $\begin{array}{l}\text { Training programs to } \\
\text { enhance technical and } \\
\text { behavioural skills of its } \\
\text { employees, there-by } \\
\text { helping the company to } \\
\text { improve productivity. }\end{array}$ & $\begin{array}{l}\text { 1,526 employees } \\
\text { were added } \\
\text { increasing the } \\
\text { total people } \\
\text { resources to } 7,096 \\
\text { worldwide }\end{array}$ & $\begin{array}{l}\text { Through various } \\
\text { programs, the } \\
\text { company seeks to } \\
\text { identify and } \\
\text { develop high } \\
\text { performers early } \\
\text { in their career. }\end{array}$ & $\begin{array}{l}\text { Selection is based } \\
\text { on merit. No } \\
\text { discrimination } \\
\text { based on caste, } \\
\text { creed, gender } \\
\text { religion etc. }\end{array}$ & $\begin{array}{l}\text { Compensation } \\
\text { package adjusted } \\
\text { annually based on } \\
\text { industry salary } \\
\text { correction, } \\
\text { compensation } \\
\text { surveys, and } \\
\text { individual } \\
\text { performance. }\end{array}$ & Nil & $\begin{array}{l}\text { Pest control, } \\
\text { hygienic offices } \\
\text { cleaned twice a } \\
\text { day. ISO } \\
\text { compliant. }\end{array}$ \\
\hline Firm C & $\begin{array}{l}\text { Great emphasis on } \\
\text { training of employees } \\
\text { at all levels to achieve } \\
\text { strategic objectives of } \\
\text { the organisation. }\end{array}$ & $\begin{array}{l}\text { Mastek group } \\
\text { employee 2,410 } \\
\text { people, compared } \\
\text { to 8,824 people } \\
\text { last year. }\end{array}$ & $\begin{array}{l}\text { Program called } \\
\text { competency } \\
\text { development } \\
\text { aligns career } \\
\text { aspiration of } \\
\text { employees with } \\
\text { organisation and } \\
\text { needs. }\end{array}$ & $\begin{array}{l}\text { No discrimination. } \\
\text { HR follows } \\
\text { expected code. }\end{array}$ & $\begin{array}{l}\text { ESOP given. Link } \\
\text { with performance. } \\
\text { Not highly } \\
\text { subsidised. Given } \\
\text { at all levels. } \\
\text { Trophies, } \\
\text { certificates, } \\
\text { citation, dinner for } \\
\text { groups, study } \\
\text { scholarships, paid, } \\
\text { etc. }\end{array}$ & $\begin{array}{l}\text { Accident } \\
\text { insurance for } \\
\text { employees } \\
\text { medical } \\
\text { insurance, life } \\
\text { insurance } \\
\text { provided by } \\
\text { company. } \\
\text { Meditation } \\
\text { room, music } \\
\text { room, canteens } \\
\text { provided. }\end{array}$ & $\begin{array}{l}\text { Security procedure } \\
\text { to enter into } \\
\text { building, fire drills } \\
\text { contingency teams } \\
\text { working round the } \\
\text { clock in case of } \\
\text { emergencies. }\end{array}$ \\
\hline
\end{tabular}




\begin{tabular}{|c|c|c|c|c|c|c|c|}
\hline Firm D & $\begin{array}{l}\text { SLC has delivered over } \\
850,000 \text { training } \\
\text { person-hours during } \\
\text { the year through } 1000+ \\
\text { programs. }\end{array}$ & $\begin{array}{l}\text { Recruited } 4,273 \\
\text { employees taking } \\
\text { the total strength } \\
\text { to } 14,032 \text { at the } \\
\text { end of the year, } \\
\text { compared to } \\
9,759 \text { at the } \\
\text { commencement } \\
\text { of the year }\end{array}$ & $\begin{array}{l}\text { SLC enables our } \\
\text { firm to maintain } \\
\text { its competitive } \\
\text { edge by } \\
\text { strategically } \\
\text { partnering with } \\
\text { business units for } \\
\text { competency } \\
\text { development and } \\
\text { enhancement of } \\
\text { employees }\end{array}$ & $\begin{array}{l}\text { EEO employer. } \\
\text { Knowledge } \\
\text { embedded is } \\
\text { important. Women } \\
\text { have flexibility at } \\
\text { work. }\end{array}$ & $\begin{array}{l}\text { Scale of } \\
\text { recognition is the } \\
\text { most important. } \\
\text { Most of the awards } \\
\text { are non-monetary } \\
\text { or has very less } \\
\text { monetary benefit } \\
\text { attached. }\end{array}$ & Nil & $\begin{array}{l}\text { Medical check ups, } \\
\text { stress management, } \\
\text { yoga, meditation } \\
\text { facilities available. } \\
\text { Online doctors and } \\
\text { counsellors for } \\
\text { physical and } \\
\text { mental health. }\end{array}$ \\
\hline Firm E & $\begin{array}{l}\text { We have structured } \\
\text { training programs } 8.74 \\
\text { training days per } \\
\text { person per annum fully } \\
\text { aligned with our new } \\
\text { business model. }\end{array}$ & $\begin{array}{l}\text { More than 3,500 } \\
\text { people worldwide }\end{array}$ & $\begin{array}{l}\text { The firm put in } \\
\text { place uniform } \\
\text { organisational } \\
\text { structure with } \\
\text { measurable } \\
\text { performance } \\
\text { metrics and career } \\
\text { progression plans. }\end{array}$ & $\begin{array}{l}\text { The concentric } \\
\text { circles we see in } \\
\text { the cross-section of } \\
\text { the firm's tree, } \\
\text { relate to the } \\
\text { diversity of our } \\
\text { people, our focus } \\
\text { and dynamism. }\end{array}$ & $\begin{array}{l}\text { The ESOP will } \\
\text { distribute } 25 \% \text { of } \\
\text { the firms equity to } \\
\text { employees and } \\
\text { presently covers } \\
26 \% \text { of the global } \\
\text { workforce. }\end{array}$ & $\begin{array}{l}\text { Transport, } \\
\text { subsidised } \\
\text { cafeteria, gym, } \\
\text { good campus, } \\
\text { basketball } \\
\text { courts, yoga, } \\
\text { aerobics } \\
\text { facilities } \\
\text { available. } \\
\text { Medical } \\
\text { insurance for } \\
\text { employees \& } \\
\text { their spouse, } \\
\text { children \& } \\
\text { dependent } \\
\text { parents }\end{array}$ & $\begin{array}{l}\text { Emergency } \\
\text { response team for } \\
\text { natural calamity, } \\
\text { fire breakout, fire } \\
\text { rehearsals \& } \\
\text { drills. Smoke } \\
\text { alarms-though not } \\
\text { mandatory is } \\
\text { available. }\end{array}$ \\
\hline
\end{tabular}




\begin{tabular}{|c|c|c|c|c|c|c|c|}
\hline Firm F & $\begin{array}{l}\text { Keeping the talent } \\
\text { contemporary is a large } \\
\text { on-going process in } \\
\text { our firm. Our annual } \\
\text { percentage of training } \\
\text { efforts exceeds } \\
100,000 \text { man-hours. }\end{array}$ & $\begin{array}{l}\text { It has grown from } \\
\text { an employee } \\
\text { strength of } 2,700 \\
\text { to } 10,000 \text { today } \\
\text { and from } \\
\text { handling } 29 \\
\text { processes to } 76 \\
\text { processes. }\end{array}$ & Nil & $\begin{array}{l}\text { The cultural } \\
\text { benefits of } \\
\text { working with a } \\
\text { multi-cultural team } \\
\text { from an } \\
\text { organisation } \\
\text { standpoint have } \\
\text { matched the } \\
\text { synergy benefits of } \\
\text { our acquisitions } \\
\text { from a customer } \\
\text { standpoint. }\end{array}$ & $\begin{array}{l}\text { The shadow stop } \\
\text { option, along with } \\
\text { Quarterly } \\
\text { performance } \\
\text { linked } \\
\text { compensation, a } \\
\text { variable pay } \\
\text { program, was the } \\
\text { other innovative } \\
\text { idea to align } \\
\text { company } \\
\text { performance with } \\
\text { employee } \\
\text { compensation. }\end{array}$ & $\begin{array}{l}\text { Transportation, } \\
\text { sabbatical leave, } \\
\text { educational } \\
\text { assistance, } \\
\text { canteen } \\
\text { facilities, } \\
\text { interest free } \\
\text { home loans, } \\
\text { external person } \\
\text { to pay bills for } \\
\text { employees. }\end{array}$ & $\begin{array}{l}\text { Safety banners, } \\
\text { squads \& } \\
\text { volunteers trained } \\
\text { on monthly basis. } \\
\text { Fire drills \& } \\
\text { natural calamity } \\
\text { trained. } 3 \text { safety } \\
\text { risks: Natural } \\
\text { calamity, fire, } \\
\text { terrorism- vehicles } \\
\text { checked, strong } \\
\text { security, electrified } \\
\text { wire }\end{array}$ \\
\hline Firm G & Nil & $\begin{array}{l}\text { From a current } \\
\text { staffing of } 474 \text { we } \\
\text { expect to reach } \\
\text { about } 2000 \text {, } \\
\text { across three } \\
\text { facilities, by the } \\
\text { end of March } \\
\text { next year to } \\
\text { service customers } \\
\text { across the globe. }\end{array}$ & Nil & Nil & Nil & Nil & Nil \\
\hline
\end{tabular}




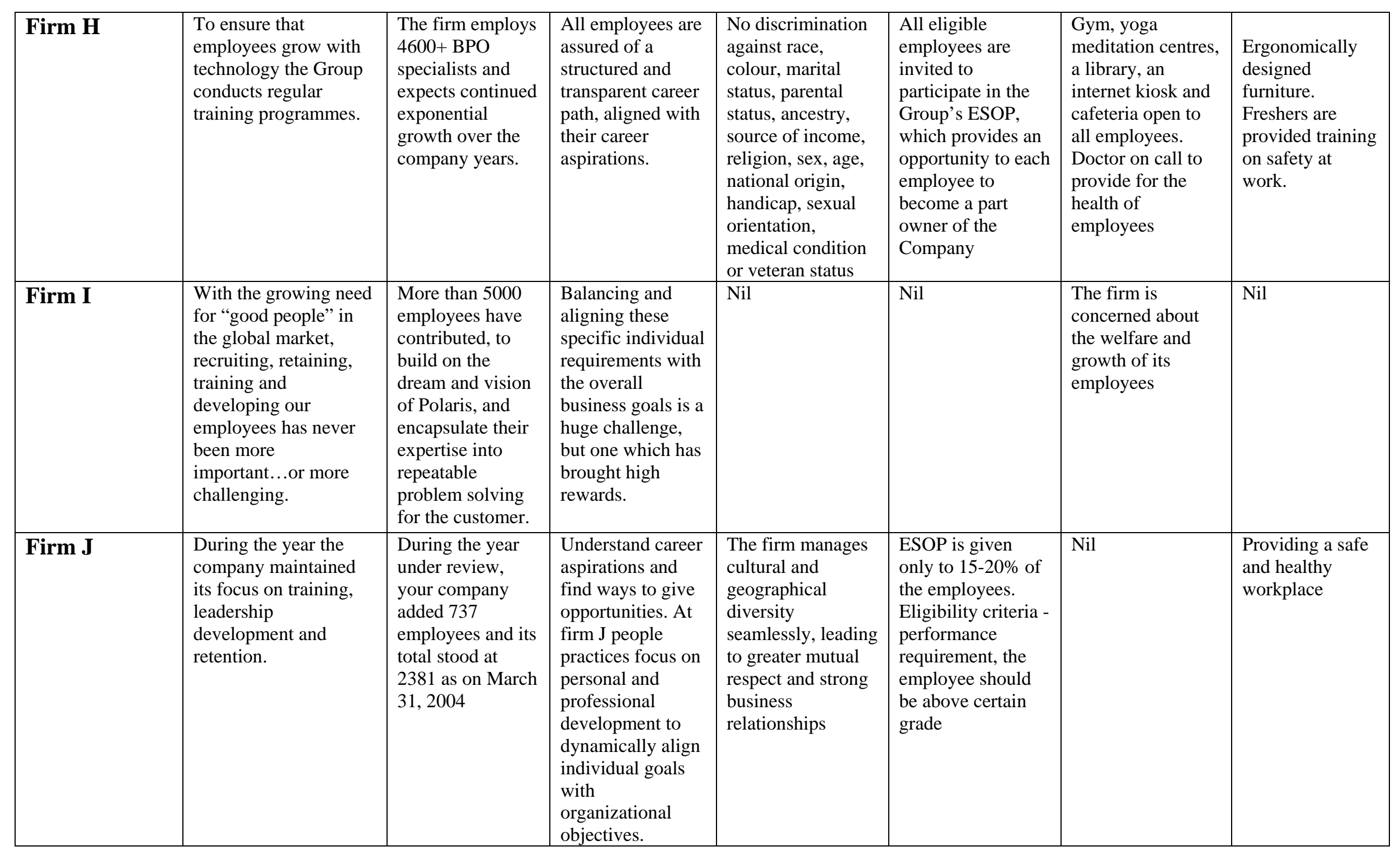




\begin{tabular}{|c|c|c|c|c|c|c|c|}
\hline Firm K & $\begin{array}{l}\text { The blend of functional } \\
\text { knowledge and } \\
\text { technical expertise, } \\
\text { coupled with our } \\
\text { training and experience } \\
\text { make our employees } \\
\text { unique. }\end{array}$ & $\begin{array}{l}\text { A net addition of } \\
266 \text { employees } \\
\text { during the fiscal } \\
\text { year taking the } \\
\text { employee } \\
\text { strength to 2,438 } \\
\text { employees. }\end{array}$ & $\begin{array}{l}\text { We have an } \\
\text { effective } \\
\text { performance } \\
\text { system with focus } \\
\text { on employee } \\
\text { development. }\end{array}$ & $\begin{array}{l}\text { We bring together } \\
\text { people with very } \\
\text { different skills, } \\
\text { backgrounds and } \\
\text { cultures. }\end{array}$ & Nil & $\begin{array}{l}\text { Lunch facility, } \\
\text { transportation } \\
\text { from major train } \\
\text { stations, health } \\
\text { centres, in-house } \\
\text { doctors, } \\
\text { counselling } \\
\text { provided with } \\
\text { external qualifies } \\
\text { counsellors, } \\
\text { medical insurance, } \\
\text { company } \\
\text { accommodation. }\end{array}$ & $\begin{array}{l}\text { Fire } \\
\text { extinguishers in } \\
\text { buildings, } \\
\text { regular fire } \\
\text { drills, training } \\
\text { given every year, } \\
\text { equipments } \\
\text { tested regularly, } \\
\text { leaders identified } \\
\text { to handle } \\
\text { emergency } \\
\text { situation }\end{array}$ \\
\hline Firm L & $\begin{array}{l}\text { The firm continues to } \\
\text { invest aggressively in } \\
\text { infrastructure, people } \\
\text { and training, all of } \\
\text { which are expected to } \\
\text { significantly contribute } \\
\text { to operations going } \\
\text { forward. }\end{array}$ & $\begin{array}{l}\text { The company } \\
\text { augmented its } \\
\text { employee } \\
\text { strength from } \\
2,490 \text { employees } \\
\text { as on March this } \\
\text { year to 5,280 } \\
\text { employees as on } \\
\text { March 31, 2004, } \\
\text { representing a } \\
\text { 111\% growth. }\end{array}$ & Nil & $\begin{array}{l}\text { EEO is a legal } \\
\text { requirement. }\end{array}$ & Nil & Nil & Nil \\
\hline Firm M & $\begin{array}{l}\text { Technical training for } \\
\text { new and existing } \\
\text { employees is an } \\
\text { ongoing process that } \\
\text { exposes the company } \\
\text { and the individual to } \\
\text { cutting edge skills and } \\
\text { technologies. }\end{array}$ & $\begin{array}{l}\text { Our 18,000 } \\
\text { talented } \\
\text { employees remain } \\
\text { committed to } \\
\text { creating and } \\
\text { delivering value } \\
\text { to all our } \\
\text { stakeholders. }\end{array}$ & $\begin{array}{l}\text { We have well set } \\
\text { career roadmaps } \\
\text { through our PTB3 } \\
\text { Stream for people } \\
\text { at all levels in the } \\
\text { organisation. }\end{array}$ & $\begin{array}{l}\text { Absolutely no } \\
\text { tolerance to } \\
\text { discrimination by } \\
\text { race, religion, } \\
\text { gender. Trying to } \\
\text { attract more } \\
\text { women employees. }\end{array}$ & $\begin{array}{l}\text { True to the firm's } \\
\text { belief in wealth } \\
\text { creation for all } \\
\text { employees, as } \\
\text { many as } 25 \% \text { of } \\
\text { employees are } \\
\text { covered under the } \\
\text { ESOP. }\end{array}$ & Nil & $\begin{array}{l}\text { Regular fire } \\
\text { drills, no } \\
\text { machine work, } \\
\text { rigorous safety } \\
\text { checks, } \\
\text { administrative } \\
\text { team to work, } \\
\text { Quake proof } \\
\text { buildings. }\end{array}$ \\
\hline
\end{tabular}




\begin{tabular}{|c|c|c|c|c|c|c|c|}
\hline Firm $\mathbf{N}$ & $\begin{array}{l}\text { To ensure the } \\
\text { availability of skills in } \\
\text { line with the business } \\
\text { needs, the firm has set } \\
\text { up extensive training } \\
\text { infrastructure. }\end{array}$ & $\begin{array}{l}\text { As of March this } \\
\text { year the firm had } \\
25,643 \\
\text { employees, as } \\
\text { compared to } \\
\text { 15,876 on March } \\
\text { 31, last year. }\end{array}$ & $\begin{array}{l}\text { As the aspirations } \\
\text { and expectations } \\
\text { of the employees } \\
\text { continue to rise, } \\
\text { only rapid growth } \\
\text { can provide } \\
\text { avenues for } \\
\text { individual } \\
\text { advancement }\end{array}$ & $\begin{array}{l}\text { Employment at } \\
\text { Infosys is based on } \\
\text { competency. Male } \\
\text { female ratio is } \\
25 \% \text {. Women have } \\
\text { a mechanism to } \\
\text { raise any concerns }\end{array}$ & $\begin{array}{l}\text { Employee } \\
\text { compensation } \\
\text { includes all direct } \\
\text { \& indirect benefits } \\
\text { earned both in } \\
\text { India and abroad }\end{array}$ & $\begin{array}{l}\text { The facilities } \\
\text { include fully } \\
\text { equipped gym, } \\
\text { aerobics, yoga, } \\
\text { meditation, health } \\
\text { clubs and } \\
\text { swimming. }\end{array}$ & $\begin{array}{l}\text { Providing its } \\
\text { employees, } \\
\text { consultants and } \\
\text { contractors with } \\
\text { a safe and health } \\
\text { environment, } \\
\text { free of } \\
\text { occupational } \\
\text { injury and } \\
\text { illness. }\end{array}$ \\
\hline Firm 0 & $\begin{array}{l}\text { Annual training } \\
\text { programs, relationships } \\
\text { with leading } \\
\text { internationally reputed } \\
\text { institutions, use of web } \\
\text { based training methods } \\
\text { etc, further provide } \\
\text { opportunities for the } \\
\text { workforce to learn new } \\
\text { skills }\end{array}$ & $\begin{array}{l}\text { The total } \\
\text { headcount } \\
\text { increased to } 3,833 \\
\text { at the end of the } \\
\text { year as compared } \\
\text { to 2,343 the } \\
\text { previous year. }\end{array}$ & $\begin{array}{l}\text { Significant focus } \\
\text { on developing } \\
\text { leadership to } \\
\text { manage future } \\
\text { growth. }\end{array}$ & $\begin{array}{l}\text { EEO is strictly } \\
\text { adhered to as the } \\
\text { policy of the } \\
\text { company. } 45 \% \\
\text { recruited are } \\
\text { women. }\end{array}$ & $\begin{array}{l}\text { ESOP given on the } \\
\text { basis of number of } \\
\text { years of } \\
\text { completion \& also } \\
\text { performance of } \\
\text { employees. }\end{array}$ & $\begin{array}{l}\text { Cafeteria, gym } \\
\text { facilities. Part of } \\
\text { curriculum-1/2 } \\
\text { hour of yoga }\end{array}$ & $\begin{array}{l}\text { Focus group for } \\
\text { safety \& security } \\
\text { of employees. } \\
\text { Late night drop } \\
\text { arranged for } \\
\text { employees. Fire } \\
\text { extinguishers, } \\
\text { fire drills, } \\
\text { periodic } \\
\text { inspections } \\
\end{array}$ \\
\hline Firm P & $\begin{array}{l}\text { We perceive training to } \\
\text { be the bridge between } \\
\text { knowledge and } \\
\text { performance, between } \\
\text { ability and deliver. }\end{array}$ & Nil & Nil & Nil & $\begin{array}{l}\text { Fine tune } \\
\text { performance } \\
\text { appraisals and } \\
\text { reward system } \\
\text { focused on results } \\
\text { accomplished and } \\
\text { effectiveness. }\end{array}$ & Nil & Nil \\
\hline
\end{tabular}




\begin{tabular}{|c|c|c|c|c|}
\hline \multirow[t]{2}{*}{$\begin{array}{l}\text { Respondent } \\
\text { Firm }\end{array}$} & \multicolumn{4}{|c|}{ Appendix 2 - Community development category. } \\
\hline & $\begin{array}{l}\text { Community planning \& } \\
\text { development }\end{array}$ & \begin{tabular}{|l|} 
Children education \& \\
upliftment of poor
\end{tabular} & Health services & Food Program \\
\hline Firm A & $\begin{array}{l}\text { The firm brings the virtues of } \\
\text { integrity, the values and } \\
\text { responsibility of honest } \\
\text { corporate citizenship. }\end{array}$ & Nil & Nil & Nil \\
\hline Firm B & $\begin{array}{l}\text { People with varied interest } \\
\text { come together and help in } \\
\text { activities for orphanage, } \\
\text { tsunami appeal, Gujarat } \\
\text { earthquake and the like }\end{array}$ & Nil & Nil & Nil \\
\hline Firm C & $\begin{array}{l}\text { Besides creating wealth for } \\
\text { shareholders and delivering } \\
\text { value to partners, our firm } \\
\text { believes it has a social } \\
\text { responsibility as well. At a } \\
\text { broader level, our Foundation } \\
\text { hopes to create a socially } \\
\text { conscious corporate India. }\end{array}$ & $\begin{array}{l}\text { Employees do voluntary social } \\
\text { course, carry out fieldwork, and } \\
\text { visit orphanages. Employees } \\
\text { give pay roll contributions to } \\
\text { society. }\end{array}$ & Nil & Nil \\
\hline Firm D & $\begin{array}{l}\text { The services volunteered by } \\
\text { employees are aimed at } \\
\text { bringing about significant and } \\
\text { lasting transformation in the } \\
\text { quality of lives of a large } \\
\text { number of people. }\end{array}$ & $\begin{array}{l}\text { The firm believes that we have a } \\
\text { responsibility to serve the } \\
\text { underprivileged and the } \\
\text { satisfaction derived from serving } \\
\text { the needy is unparalleled. }\end{array}$ & $\begin{array}{l}\text { The employees volunteered } \\
\text { for tsunami relief, } \\
\text { calamities, they adopt } \\
\text { villages to care for health \& } \\
\text { safety. }\end{array}$ & Nil \\
\hline Firm E & $\begin{array}{l}\text { The basic justification for our } \\
\text { business to exist is to create } \\
\text { economic value - for its } \\
\text { stakeholders, its employees } \\
\text { and for the community at } \\
\text { large. }\end{array}$ & $\begin{array}{l}\text { The employees are involved in } \\
\text { caring for Children \& their } \\
\text { education Computers were } \\
\text { donated, employees teach } \\
\text { computers, help with } \\
\text { infrastructure. }\end{array}$ & Nil & Nil \\
\hline
\end{tabular}




\begin{tabular}{|c|c|c|c|c|}
\hline Firm F & $\begin{array}{l}\text { Our firm is an element in the } \\
\text { social fabric, and unless we } \\
\text { expand possibilities for the larger } \\
\text { community, we will not create } \\
\text { significant growth opportunities } \\
\text { for ourselves. }\end{array}$ & $\begin{array}{l}\text { Employees have helped in tsunami, } \\
\text { natural disasters, slum education, } \\
\text { health, hygiene, professional } \\
\text { training like driving, tailoring etc for } \\
\text { poor \& needy. }\end{array}$ & Nil & Nil \\
\hline Firm G (NIIT) & Nil & Nil & Nil & Nil \\
\hline Firm H & $\begin{array}{l}\text { Putting in place an employee and } \\
\text { volunteer-driven organization } \\
\text { structure, which will spearhead } \\
\text { community initiatives across the } \\
\text { organization. }\end{array}$ & $\begin{array}{l}\text { Employees contribute to the } \\
\text { education and recreational activities } \\
\text { of poor children by donating their } \\
\text { skills and time }\end{array}$ & Nil & $\begin{array}{l}\text { Akshiya pathra-mid-day meal } \\
\text { to school children. }\end{array}$ \\
\hline Firm I & Nil & $\begin{array}{l}\text { Our volunteers spend quality time } \\
\text { over weekends, mentoring the } \\
\text { young minds. Children given } \\
\text { training in English language skills, } \\
\text { painting competitions, and career } \\
\text { counselling sessions. }\end{array}$ & Nil & Nil \\
\hline Firm J & $\begin{array}{l}\text { The Carterpuri (Village adoption) } \\
\text { cause received a great boost by } \\
\text { the active "Give as You Earn" } \\
\text { campaign, through which } \\
\text { employees have contributed a } \\
\text { percentage of their earnings to } \\
\text { this project, setting an example of } \\
\text { corporate responsiveness. }\end{array}$ & $\begin{array}{l}\text { The Outreach Programme has seen } \\
\text { increased involvement from our } \\
\text { employees, who have actively } \\
\text { volunteered to teach at the school. }\end{array}$ & $\begin{array}{l}\text { Employees give donations } \\
\text { for Gujarat earthquake, } \\
\text { natural disasters in Assam, } \\
\text { Rajasthan, and care for the } \\
\text { health of victims and the } \\
\text { company matched the } \\
\text { donations. }\end{array}$ & Nil \\
\hline Firm K & $\begin{array}{l}\text { Employees are involved in all the } \\
\text { activities and money from trust } \\
\text { utilised for the purpose. They } \\
\text { involve in maintenance of local } \\
\text { police station, lakes, parks and } \\
\text { environment. }\end{array}$ & $\begin{array}{l}\text { Our "Firm K for children" } \\
\text { community initiative is focused on } \\
\text { improving children's education and } \\
\text { health }\end{array}$ & $\begin{array}{l}\text { Company contributed equal } \\
\text { amount as employee } \\
\text { contribution for tsunami } \\
\text { victims }\end{array}$ & Nil \\
\hline Firm L & $\begin{array}{l}\text { Our firm continued initiating and } \\
\text { espousing various social and } \\
\text { environmental causes in areas that } \\
\text { included primary education, } \\
\text { healthcare, day care services and } \\
\text { community development }\end{array}$ & $\begin{array}{l}\text { Our Outreach Onsite program } \\
\text { contributed to improving the } \\
\text { opportunities available to the under } \\
\text { privileged children of rural migrants } \\
\text { to Bangalore. }\end{array}$ & $\begin{array}{l}\text { In addition, general health } \\
\text { and awareness camps were } \\
\text { organized for training in } \\
\text { personal hygiene. }\end{array}$ & $\begin{array}{l}\text { In the past, our firm's trust has } \\
\text { initiated providing essential facilities } \\
\text { like midday meals and drinking water } \\
\text { to the underprivileged. }\end{array}$ \\
\hline
\end{tabular}




\begin{tabular}{|c|c|c|c|c|}
\hline Firm M & Nil & $\begin{array}{l}\text { Employees participate in } \\
\text { providing ongoing help to the } \\
\text { destitute. }\end{array}$ & $\begin{array}{l}\text { One-day salary donated to } \\
\text { tsunami victims. Surgical } \\
\text { gloves etc distributed. }\end{array}$ & Nil \\
\hline Firm N & $\begin{array}{l}\text { Our firm's trust helps preserve } \\
\text { certain arts and cultural } \\
\text { activities in India, which are } \\
\text { under threat of dying out. }\end{array}$ & $\begin{array}{l}\text { The foundation supports } \\
\text { programs and organizations } \\
\text { devoted to the cause of the } \\
\text { destitute, rural poor, mentally } \\
\text { challenged, belonging to the } \\
\text { economically backward sections } \\
\text { of the society. }\end{array}$ & $\begin{array}{l}\text { Employees provided } \\
\text { medical relief for the flood- } \\
\text { hit village of Bangrisingha, } \\
\text { Orissa; donations to the } \\
\text { SOS village of Rajpura }\end{array}$ & $\begin{array}{l}\text { Our employees of } \\
\text { Mangalore Centre launched } \\
\text { a mid-day meal scheme for } \\
\text { the children of St. Peters } \\
\text { School. }\end{array}$ \\
\hline Firm 0 & $\begin{array}{l}\text { Our firm has consistently } \\
\text { responded to various } \\
\text { community initiative programs } \\
\text { and understands the larger role } \\
\text { that it can play in social } \\
\text { development. }\end{array}$ & Nil & $\begin{array}{l}\text { In the wake of the Tsunami } \\
\text { disaster, which left } \\
\text { thousands homeless, the } \\
\text { company and its employees } \\
\text { contributed Rs. } 1 \text { crore for } \\
\text { the relief and rehabilitation } \\
\text { of the affected families. }\end{array}$ & Nil \\
\hline Firm P & $\begin{array}{l}\text { Our firm fosters a culture of } \\
\text { caring, trust and continuous } \\
\text { learning while meeting } \\
\text { expectations of employees, } \\
\text { stakeholders and society. The } \\
\text { company is firmly committed } \\
\text { to serve the society through its } \\
\text { community welfare programs }\end{array}$ & $\begin{array}{l}\text { We recognize the inherent } \\
\text { potential and immense impact of } \\
\text { education on society. We also } \\
\text { assist village schools by } \\
\text { providing infrastructural support } \\
\text { that ranges from basic teaching } \\
\text { aids to computers. } \\
\text { Young girls and boys are trained } \\
\text { in skills like tailoring, typing, } \\
\text { screen-printing, Seri-culture, } \\
\text { animal husbandry, papad and } \\
\text { pickle making, fruit } \\
\text { preservation, dairy and poultry } \\
\text { training. }\end{array}$ & $\begin{array}{l}\text { Have health centres to take } \\
\text { care of mother \& child } \\
\text { health, AIDS victims, TB } \\
\text { patients, skin disorders, eye } \\
\text { testing \& surgery for } \\
\text { economically deprived. }\end{array}$ & Nil \\
\hline
\end{tabular}

